\title{
THE TRANSITION METAL TO LIGAND BONDING NATURE: A QUANTUM CHEMICAL STUDY OF $\pi$-ALLYL-RUTHENACYCLE MOLECULE
}

\author{
A. Vektarienè \\ Institute of Theoretical Physics and Astronomy, Vilnius University, Sauletekio 3, 10257 Vilnius, Lithuania \\ Email: ausra.vektariene@tfai.vu.lt
}

Received 23 March 2018; revised 6 May 2018; accepted 21 June 2018

\begin{abstract}
Understanding of the transition metal (TM) to ligand (L) bonding nature is important for characterization of experimental observations. One of the methods to explain the TM to L interactions is the Dewar-Chatt-Duncanson (DCD) model. However, in most applications the validity of the DCD model is based on assumptions in order to explain trends in vibrational spectroscopy or other physical properties of TM complexes. In this paper the computational methodology for treatment of the $\pi$-allyl-ruthenacycle complex based on the density functional theory, restricted Hartree-Fock method, natural bond orbital and charge decomposition analysis is reported. It is shown how the DCD model emerges from the presented calculation scheme and how it relates with the physical properties and stability of this complex. It is important to note that in this work the determination of the DCD model operation is based on the defined computational procedure, not postulated beforehand. The calculated geometry parameters, vibrational frequencies and electron density arrangement for the $\pi$-allyl-ruthenacycle complex are in good agreement with the experiment and support the DCD model.
\end{abstract}

Keywords: Dewar-Chatt-Duncanson model, density functional theory, natural bond orbitals, charge decomposition analysis

PACS: $31.10 .+z, 31.15 . A-$

\section{Introduction}

An impressive development in the reliability of quantum chemistry methods leads to their applications in solving physical phenomena from light to heavy-atom molecular systems. Moreover, it becomes possible to treat systems like transition metal coordinated ligands with the accuracy comparable to that of the experiment. A comprehensive physical understanding of the transition metal (TM) to ligand (L) bonding nature is of great importance for metallacatalysis [1, 2] and electro-luminescence processes in organic light emitting devices [3, 4 . The most widely used bonding model for TM complexes is the crystal field theory which considers electrostatic interactions between the metal and the ligand environment. Alternatively, the ligand field theory can also be considered for molecular TM bonding treatments [5-8]. The ligand field theory is a simplified molecular orbital (MO) theory which considers mainly the valence d orbitals of TM and frontier orbitals of L. Another MOtheoretical model is the Dewar-Chatt-Duncanson (DCD) model [9, 10]. It considers TM-L interactions in terms of the $\mathrm{L} \rightarrow \mathrm{TM}$ electron donation and the $\mathrm{L} \leftarrow \mathrm{TM}$ electron back-donation. This model was originally introduced by Dewar, Chatt and Duncanson [ [9, 10] to describe TM-olefin, TMcarbonyl and TM-carbenes interactions. The essence of this model is schematically represented in Fig. 1 by application to one $\mathrm{Ru}-\mathrm{CO}$ bond from the $\pi$-allyl-ruthenacycle complex $(\mathrm{Ru}-\mathrm{L})$. 


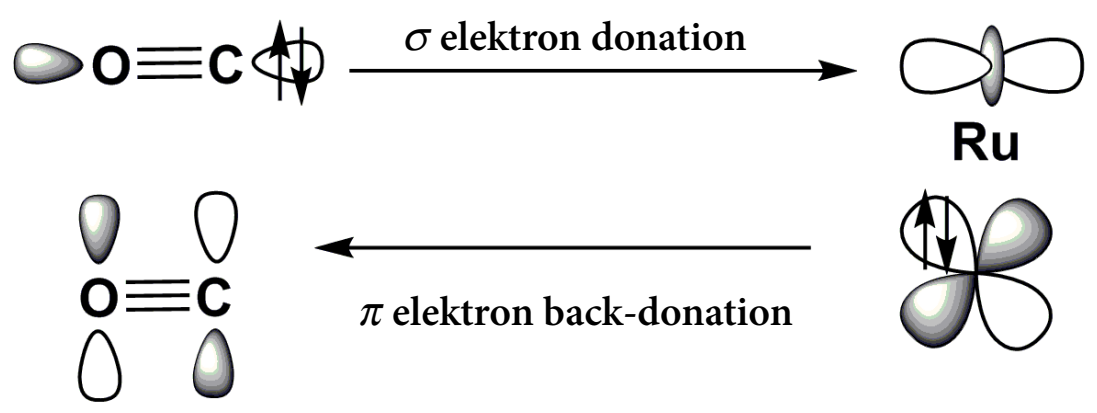

Fig. 1. The DCD model in Ru-L. The CO bond donates $\sigma$-electrons to the $\mathrm{Ru}$ atom. The electron back-donation proceeds from the $\mathrm{d}$ orbitals of $\mathrm{Ru}$ into the electron accepting antibonding $\pi$ orbitals of the $\mathrm{CO}$ bond.

The $\mathrm{Ru}$-CO $\sigma$-bond is formed by electron donation (ED) from an occupied $\sigma$ molecular orbital of CO into an empty orbital of the central $\mathrm{Ru}$ atom [11]. This ED process $\mathrm{Ru} \leftarrow \mathrm{CO}$ leads to an electron excess at the $\mathrm{Ru}$ atom, which is energetically unfavourable. Therefore the electron back-donation (EBD) then occurs from the occupied d orbitals of the $\mathrm{Ru}$ atom into the empty $\pi$-MOs of the CO ligand to minimize this electron access. Consequently, EBD induces shortening of the TM-L bond and elongation of the $\mathrm{L}$ bond influenced by electron transfer. This shortening and elongation has been discussed in literature [11, 12].

The DCD is frequently used as a very powerful model to explain trends in geometries, vibrational spectroscopy, and other physical properties of TM complexes.

Spectroscopic data like vibration frequencies are correlated with the $\pi$ acceptor strength of ligands. For example, elongation of the $\mathrm{CO}$ bond in the TM-CO can be indicated by lowering of $\mathrm{CO}$ vibration frequencies [11, 12]. Moreover, changes in the reactivity of ligand functional groups can be also described in accordance with the DCD model [13]. Thus, the DCD model describes essential properties of TM-L bonds. However, in most studies the validity of the DCD model is only based on beforehand assumptions in order to explain the trends in molecular geometries, vibrational spectroscopy, and other physical properties of TM complexes.

Thus, several issues of TM-L bonding should be clarified beyond a qualitative estimation of the DCD model: how the environment of TM and ligand is operating in the electron density rearrangement; how it reflects the physical properties and stability of $\mathrm{Ru}-\mathrm{L}$; how the electron transfer influences the lowering of the molecular energy of the $\mathrm{Ru}-\mathrm{L}$ complex.

To rationalize these issues, knowing the energies and shapes of the relevant donor and acceptor MOs involved in EBD and ED is very important. However, in most applications of the DCD model, the main donor and acceptor MOs are only assumed to be known beforehand.

This work is the first theoretical study of the $\pi$-allyl-ruthenacycle compound $(\mathrm{Ru}-\mathrm{L})$ stabilized with two carbonyl and cyclometallated $\pi$-allyl-oxapyridyl ligands. The novel $\mathrm{Ru}$-complex serves as a stable intermediate in the effective reversible Ru catalyzed metallacycle reaction. In this paper the computational methodology for treatment of the $\mathrm{Ru}-\mathrm{L}$ based on the density functional theory (DFT), restricted Hartree-Fock method (HF), natural bond orbital (NBO) [20-22] and charge decomposition analysis (CDA) [23] is reported. It is shown how the DCD model emerges from the presented calculation scheme when it is applied to the complex $\pi$-allyl-ruthenacycle compound and how it reflects the physical properties and stability of $\mathrm{Ru}-\mathrm{L}$.

\section{Methods and the proposed computational methodology}

\subsection{Methods}

All computations on $\mathrm{Ru}-\mathrm{L}$ have been performed using the Gaussian09 program [24]. The hybrid B3LYP functional [25, 26] is the most popular density functional that yields suitable structural and thermochemical characters in the computational studies of cyclic molecules and TM cataly- 
sis 27-37. The use of the SVP basis set is the best compromise between speed and accuracy in computations of transition metal complexes [38, 39]. Thus, the hybrid B3LYP functional and the split valence polarized (SVP) basis set have been used for the treatment of $\mathrm{Ru}-\mathrm{L}$. The stationary points were characterized as minima by calculation of the Hessian matrix and vibration analysis. Computed and experimental data of the solid state $\mathrm{X}$-ray analysis as well as $\mathrm{CO}$ vibrational frequencies taken from [40] for $\mathrm{Ru}-\mathrm{L}$ are provided in Table 1 . The B3LYP/SVP optimized geometry of $\mathrm{Ru}-\mathrm{L}$ was used for the NBO analysis [20-22]. The NBO analysis has been carried out with the internal module of Gaussian09 at the B3LYP/SVP level of theory. The role of electron delocalization in the $\mathrm{Ru}-\mathrm{L}$ was quantitatively assessed by deleting all non-Lewis NBOs. Deletion of all non-Lewis orbitals was performed as implemented in the NBO program. The bonding between $\mathrm{Ru}$ and $\mathrm{L}$ fragments was further investigated by CDA developed by Frenking [23]. Structures and molecular orbitals were modelled with the GaussView 5 software [43].

\subsection{Proposed methodology revealing the DCD model operation}

A suitable way to disclose the DCD model operation within the $\mathrm{Ru}-\mathrm{L}$ is to perform a computational NBO analysis which may provide detailed insights into the Lewis electron dot structure of a molecule. It is well known that for chemists the Lewis structure is a basis representing a qualitative notation of the electronic structure in a molecule [14].

A molecule in the Lewis structure consists of electron pairs localized at lone pairs or core atoms, and at the bonds between atoms. In physics the most standard methods are considering the overall electronic structure of a molecule consisting of one electron wave functions - delocalized canonical molecular orbitals (MOs) that are distributed over the whole spatial region on atoms in a molecule as defined in the HF or Kohn-Sham molecular orbitals (MOs) in DFT methods.

Localized doubly occupied MOs can be constructed by the unitary transformation of delocalized canonical MOs being doubly occupied in the closed shell HF calculation [15-19]. Weinhold et al. have found a way to obtain the Lewis struc- ture from delocalized canonical MOs [20-22]. This leads to orthogonal NBOs with electron occupation numbers. All obtained NBOs are divided into segments having the following different electron population levels on each NBO:

(a) Core NBOs occupied by two electrons on atoms (CR);

(b) Bonding localized NBOs strongly occupied by electrons on bonds (BD) or lone pairs (LP);

(c) Antibonding 'non-Lewis' orbitals - NBOs weakly occupied by electrons $\left(\mathrm{BD}^{\star}, \mathrm{LP}^{\star}\right)$;

(d) Almost empty delocalizing Rydberg (RY) NBOs.

The NBOs restore the bonding nature and electronic structure of a molecule and are used as an informative tool for the estimation of physical and chemical properties of molecules. This model can explain the DCD bonding phenomenon in a molecular Lewis structure. Meanwhile, such relationship is difficult to observe when the DCD model is explored by means of canonical MOs.

In this work the Weinhold and Landis's computational scheme [20-22] was applied to obtain NBOs for the Ru-L complex. Firstly, it was shown how the occupied BD and LP NBOs represent the Lewis structure of the $\mathrm{Ru}-\mathrm{L}$ complex. Secondly, the most important NBO interactions between the strongly occupied NBOs of BD, LP and 'non Lewis' weakly occupied antibonding $\mathrm{BD}^{\star}, \mathrm{LP}^{\star} \mathrm{NBO}$ have been determined applying the Weinhold's perturbation technique [21]. This outcome enables one to qualitatively estimate the extent of electron density transferred from the occupied BD and LP NBOs of the (b) segment to the formally vacant $\mathrm{BD}^{\star}$ and $\mathrm{LP}^{\star} \mathrm{NBO}$ of the (c) segment. In this way finding the electron donor or acceptor ability of each ligand to TM bond involved in EBD and ED has been accomplished by applying the Weinhold's perturbation technique [21]. This enables one to explain the trend how the bond length, strengths and vibrational frequencies are correlated with the electron donating-accepting strength of the $\mathrm{Ru}$ to ligand bonds. Aiming to confirm the tendencies obtained from the electron transfer characterization by NBO analysis the role of electron transfer has also been quantitatively assessed by CDA [23]. This method provides the possibility to define the amount of energy transferred by electrons in $\mathrm{ED}$ (donation from the ligand to TM) and in EBD 
(back-donation from the TM to ligand) for each molecular orbital. Thus, the DCD model emerges from the proposed computations. In this way, the determination of the DCD model operation is based on a defined computational procedure.

\section{Results and discussions}

\subsection{The structure of $\pi$-allyl-ruthenacycle $(R u-L)$}

The computed and experimental data of solid state $\mathrm{X}$-ray analysis as well as the $\mathrm{CO}$ vibration frequencies taken from [40] for $\mathrm{Ru}-\mathrm{L}$ are reported in Table 1.

In general, the calculated and the experimental values are found to be in good agreement which may indicate that the chosen method is appropriate for a theoretical description of the $\mathrm{Ru}-\mathrm{L}$ type of compounds. It can be seen from Table 1 that the calcu- lated geometry parameters between $\mathrm{Ru}$ and $\mathrm{L}$ atoms are somewhat larger than the experimental values. The solid-state interactions can lead to shortening of donor-acceptor transition metal (TM) to ligand bonds due to different intermolecular forces as compared to those calculated in the gas phase [41, 42].

Nevertheless, the results obtained from the gasphase computation are more appropriate for the evaluation of a discrete $\mathrm{Ru}-\mathrm{L}$ molecule as compared to those of the crystal solid state. The $\mathrm{Ru}-\mathrm{L}$ adopts a slightly distorted octahedral configuration as it is evident from the presented optimized geometry (Fig. 2).

The Ru atom coordination to ligands consists of the linear coordination of two bondings ( $5^{\prime}-\mathrm{Ru}$ and $\mathrm{Ru}-\mathrm{C} 9 \mathrm{O}$ bonds bearing axial positions) and four equatorial coordination states (two bonds of the $\mathrm{Ru}$ atom with $\mathrm{C} 1$ and $\mathrm{C} 3$ atoms, one bond of $\mathrm{Ru}$ with the $\mathrm{N}$ atom, and the bond of $\mathrm{Ru}$ with the $\mathrm{C} 8$ atom).

Table 1. Comparison between the B3LYP/SVP level computed (columns 3 and 7) and experimental [40] (columns 2 and 6) bond lengths, angles and vibrational $\mathrm{CO}$ frequencies for the $\mathrm{Ru}-\mathrm{L}$ complex. The calculated Wiberg bond order index (WI) and the bond occupancy by electron values are listed in columns 4 and 5 .

\begin{tabular}{|c|c|c|c|c|c|c|}
\hline Entry & $\begin{array}{c}\text { Exp. [40] } \\
\text { geom. param. }\end{array}$ & $\begin{array}{l}\text { Calc. bond } \\
\text { lengths }\end{array}$ & WI & $\begin{array}{l}\text { Occu- } \\
\text { pancy }\end{array}$ & $\begin{array}{l}\text { Exp. [40] vib. } \\
\text { freq. } \mathrm{cm}^{-1}\end{array}$ & $\begin{array}{l}\text { Calc. vib. } \\
\text { freq. } \mathrm{cm}^{-1}\end{array}$ \\
\hline 1 & 2 & 3 & 4 & 5 & 6 & 7 \\
\hline $\mathrm{Ru}-\mathrm{C} 1$ & 2.187 & 2.235 & 0.5568 & 1.52778 & - & - \\
\hline $\mathrm{Ru}-\mathrm{C} 3$ & 2.277 & 2.308 & 0.4456 & 1.47119 & - & - \\
\hline $\mathrm{Ru}-\mathrm{O} 5^{\prime}$ & 2.059 & 2.081 & 0.3624 & 1.90426 & - & - \\
\hline $\mathrm{Ru}-\mathrm{N}$ & 2.131 & 2.199 & 0.4448 & 1.65617 & - & - \\
\hline $\mathrm{Ru}-\mathrm{C} 8 \mathrm{O}$ & 1.903 & 1.927 & 1.1108 & 1.91093 & - & 431 \\
\hline $\mathrm{Ru}-\mathrm{C} 9 \mathrm{O}$ & 1.865 & 1.903 & 1.2343 & 1.99807 & - & 454 \\
\hline $\mathrm{C} 8=\mathrm{O}$ & 1.138 & 1.140 & 2.1383 & $\begin{array}{l}1.99760 \\
1.99302 \\
1.99302 \\
\end{array}$ & 2014 & 2135 \\
\hline $\mathrm{C} 9=\mathrm{O}$ & 1.151 & 1.152 & 2.0913 & $\begin{array}{l}1.99807 \\
1.99776 \\
1.99119\end{array}$ & 1941 & 2071 \\
\hline $\mathrm{C} 9-\mathrm{Ru}-\mathrm{N}$ & 100.2 & 99.8 & - & - & - & - \\
\hline $\mathrm{C} 9-\mathrm{Ru}-\mathrm{C} 3$ & 99.4 & 101.2 & - & - & - & - \\
\hline $\mathrm{C} 9-\mathrm{Ru}-\mathrm{C} 8$ & 91.6 & 92.4 & - & - & - & - \\
\hline $\mathrm{C} 9-\mathrm{Ru}-\mathrm{C} 1$ & 99.9 & 102.9 & - & - & - & - \\
\hline $\mathrm{O} 5{ }^{\prime}-\mathrm{Ru}-\mathrm{C} 3$ & 80.8 & 79.9 & - & - & - & - \\
\hline $\mathrm{O} 5{ }^{\prime}-\mathrm{Ru}-\mathrm{C} 8$ & 88.8 & 87.4 & - & - & - & - \\
\hline $\mathrm{O} 5{ }^{\prime}-\mathrm{Ru}-\mathrm{C} 1$ & 83.7 & 82.0 & - & - & - & - \\
\hline $\mathrm{C} 8-\mathrm{Ru}-\mathrm{C} 3-\mathrm{O} 8{ }^{\prime}$ & 178.3 & 178.2 & - & - & - & - \\
\hline C9-Ru-O5'-O9' & 171.2 & 177.6 & - & - & - & - \\
\hline
\end{tabular}




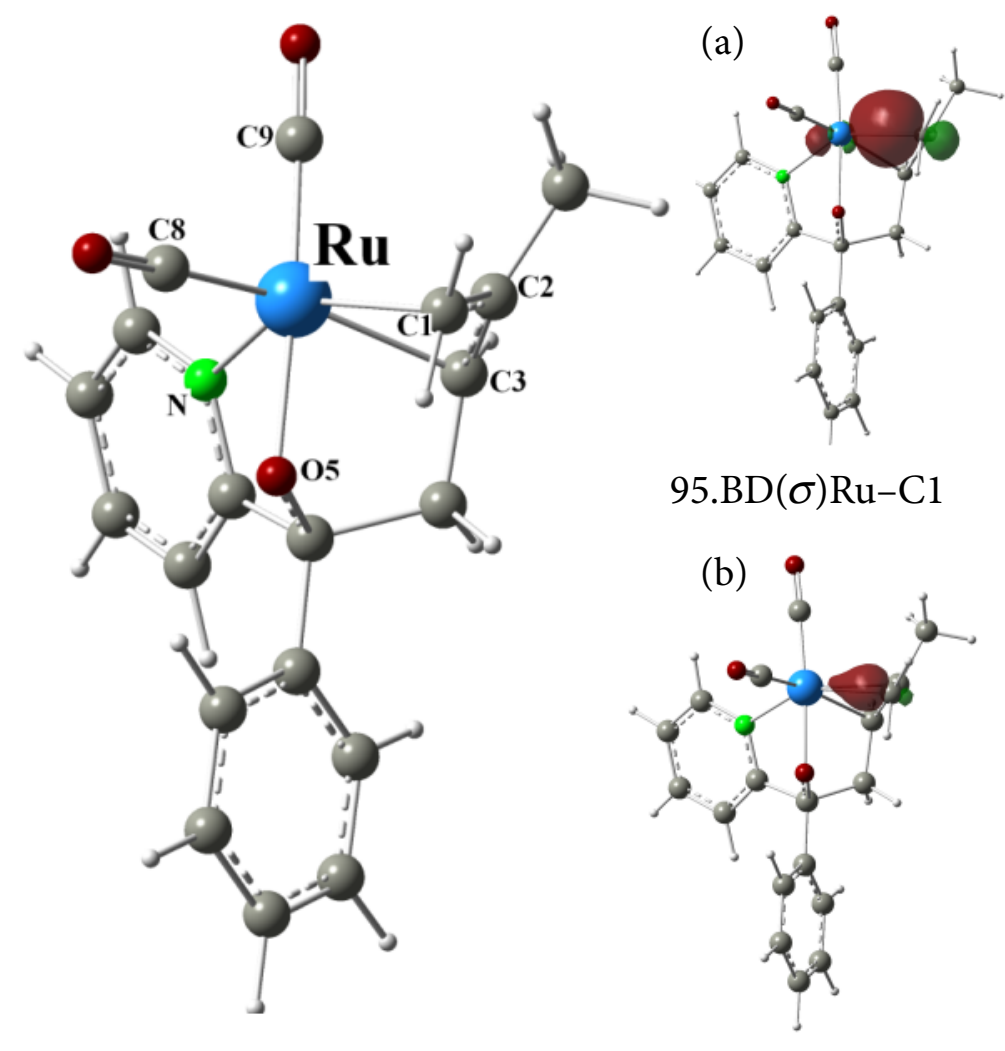

Fig. 2. The optimized geometry of Ru-L at the B3LYP/SVP level. NBOs 95 representing an equatorial $\mathrm{Ru}-\mathrm{C} 3 \sigma$-bond: isosurface value of 0.09 (a) and isosurface value of 0.17 (b).

The two $\mathrm{Ru}-\mathrm{CO}$ bonds are not equal. An increase in the $\mathrm{Ru}-\mathrm{C} 9 \mathrm{O}$ coordination strength results in the decreased strength of the $\mathrm{C} 9=\mathrm{O}$ bond. The calculated shorter axial $\mathrm{Ru}-\mathrm{C} 9 \mathrm{O}$ bond distance of $1.90 \AA$ leads to an increase in the $\mathrm{C} 9=\mathrm{O}$ bond length $(1.52 \AA)$ and, vice versa, the longer equatorial $\mathrm{Ru}-\mathrm{C} 8 \mathrm{O}$ bond distance of $1.93 \AA$ leads to a decrease in the $\mathrm{O}=\mathrm{C} 8$ bond length $(1.14 \AA)$. Experimental [40] $\mathrm{Ru}-\mathrm{CO}$ bond lengths are properly reproduced by the DFT calculation (Table 1). The B3LYP calculation yields $\mathrm{CO}$ vibration frequencies which are overestimated by about $125 \mathrm{~cm}^{-1}$ compared to the experiment (Table 1). However, the calculated and experimental frequencies reveal that the longer $\mathrm{C} 9=\mathrm{O}$ bond distance is associated with the lower $\mathrm{C} 9=\mathrm{O}$ vibration frequency as compared to that of $\mathrm{C} 8=\mathrm{O}$.

It is well known that almost in all cases the axial TM-CO bond in a complex should be slightly longer than the equatorial TM-CO bond. The TM$\mathrm{CO}$ bonding of the $\mathrm{Ru}-\mathrm{L}$ complex is an exception to this rule. The increased axial $\mathrm{Ru}-\mathrm{C} 9 \mathrm{O}$ coordination strength might appear due to complicated
ED and EBD effects in the $\mathrm{Ru}-\mathrm{L}$ complex. This phenomenon could be rationalized by means of the TM to ligand bonding model as suggested by DCD [9, 10].

\subsection{The computed Lewis structure for $\pi$-allyl- ruthenacycle $(R u-L)$}

The validity of the DCD model within the $\mathrm{Ru}-\mathrm{L}$ has been disclosed by means of a computational NBO analysis. The optimized geometry of the $\mathrm{Ru}-\mathrm{L}$ has been used to obtain the NBOs [24. The strongly occupied NBOs represent the Lewis structure of $\mathrm{Ru}-\mathrm{L}$ and provide information for determination of important interactions between $\mathrm{BD}, \mathrm{LP}$ NBOs and non-Lewis antibonding $\mathrm{BD}^{\star}, \mathrm{LP}^{\star}$ NBOs. Following this, the relevant set constructed from the occupied NBOs classifying NBOs as BD and LP has been analysed. Assignment of the NBOs has been made by monitoring the output results, shapes and locations in the space of NBOs with the GausView 5 program [43]. Figure 3 presents the Lewis structure of the $\mathrm{Ru}$-complex as it was obtained from 


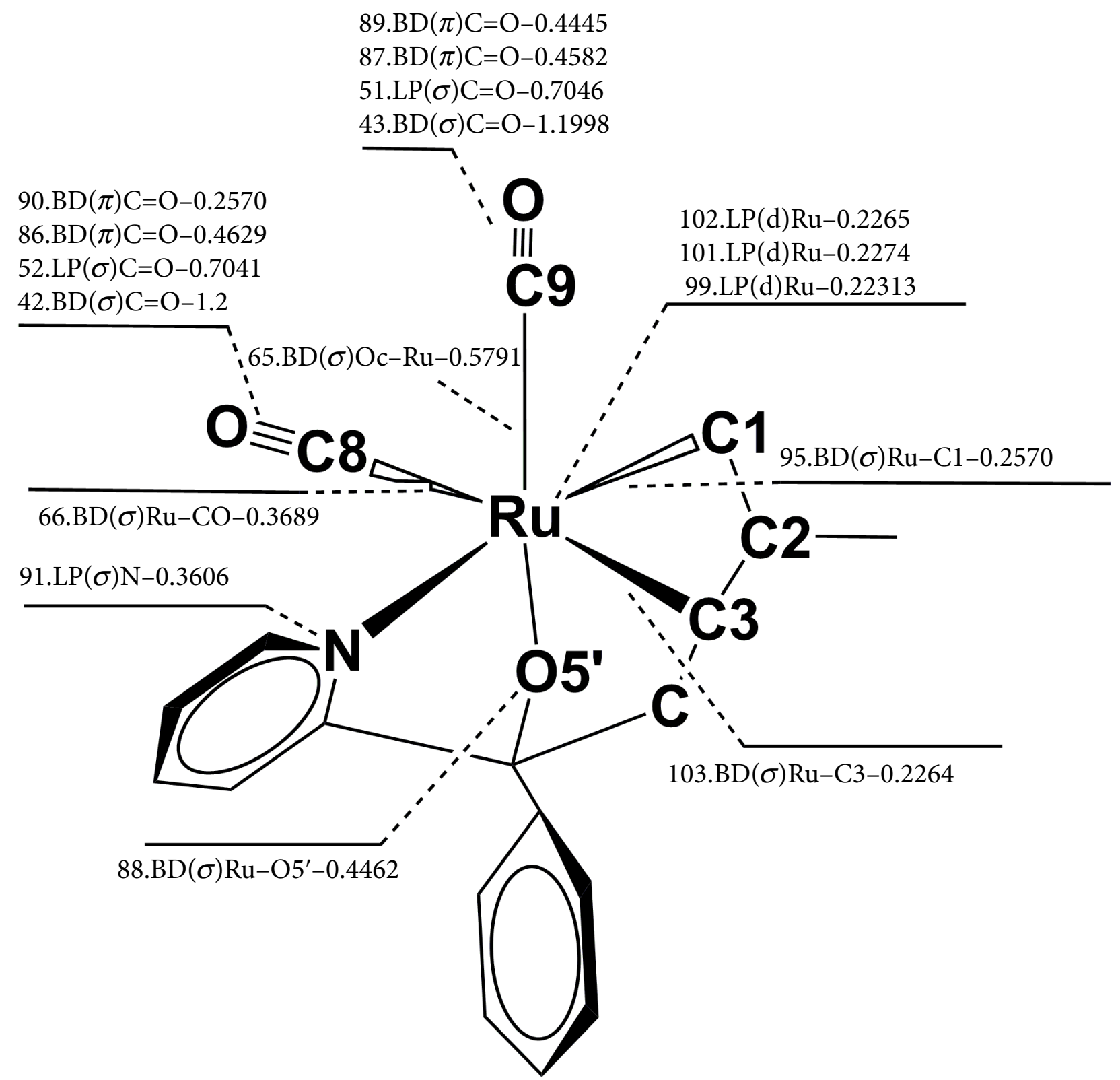

Fig. 3. The Lewis structure of the Ru-L complex. The NBO numbers, BD or LP type, and $\sigma, \pi, d$ bond character as well as the orbital energy (in a.u.) for each NBO are denoted.

the shape and location of NBOs. The BD and LP NBOs occupy the positions from 41 to 103 in order of increasing energy. The Wiberg index (WI) values (bond strength measure) and electron occupancies on the bond obtained by NBO have been collected in Table 1 .

The important notion about $\mathrm{Ru}-\mathrm{L}$ comes from the NBOs inspection of $\pi$-allyl ligand interactions with the $\mathrm{Ru}$ atom. As represented in Fig. 2(a), the plots of NBO shapes at isosurface values of 0.09 show that NBO 95 and NBO 98 represent nearly equatorial $\mathrm{Ru}-\mathrm{C} \sigma$-bonds as presented in Fig. 2(a). The $\mathrm{Ru}-\mathrm{C} 3$ bond was found to be weaker than that of $\mathrm{Ru}-\mathrm{C} 1$. The $98 . \mathrm{BD}(\sigma) \mathrm{C} 3-\mathrm{Ru} \mathrm{NBO}$ has 0.031 a.u. higher energy compared to that of $95 . \mathrm{BD}(\sigma) \mathrm{C} 1-$ $\mathrm{Ru}$. The $\mathrm{Ru}-\mathrm{C} 3$ bond is more polarized and less occupied by electrons than $\mathrm{Ru}-\mathrm{C} 1$. The electron occupation numbers are 1.47 and 1.53 , and WI is 0.45 and 0.56 , respectively. Both $\mathrm{Ru}-\mathrm{C}$ bonds are polarized towards the carbon atom as shown by plots of the 0.17 isovalue (Fig. 2(b)) and display an extensive contribution of the $\mathrm{Ru}$ atom $\mathrm{d}$ electrons to the bond formation. This finding is compatible with a significant polarized covalent bonding character of the bonds $\mathrm{Ru}-\mathrm{C}$. As shown in Fig. 4, the three occupied d-type LP orbitals $\left(99 \mathrm{~d}^{x z}\right.$, 


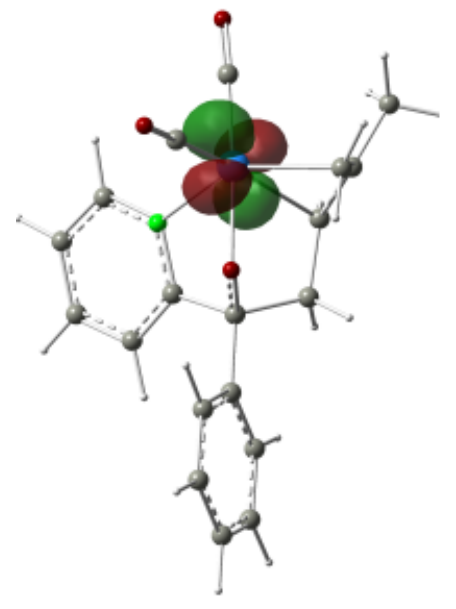

99.LP(d)Ru

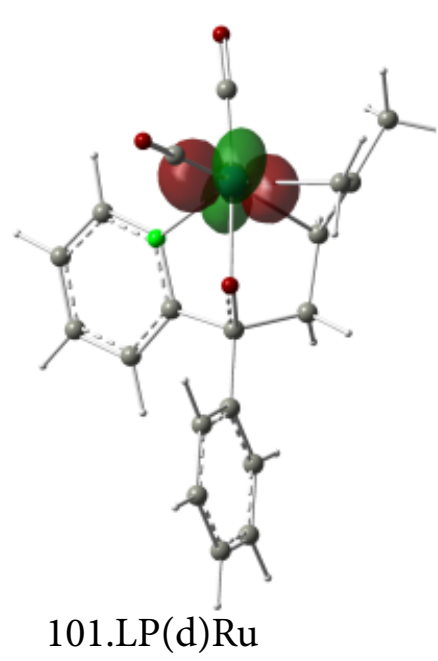

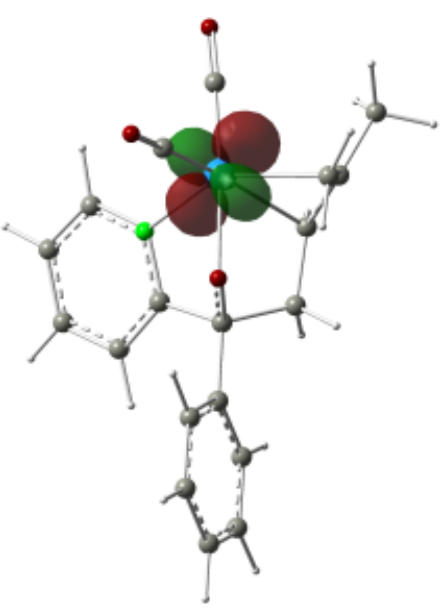

102.LP(d)Ru

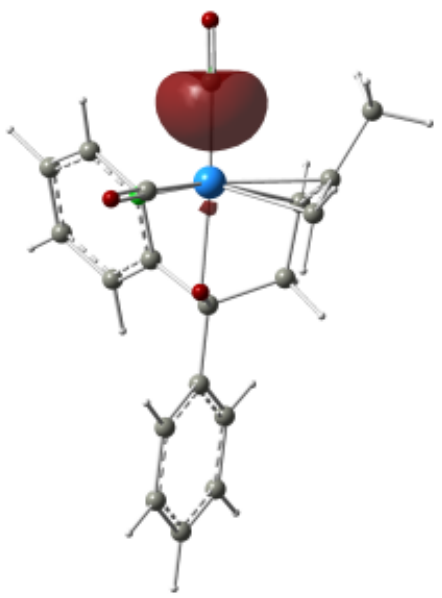

65. $\mathrm{BD}(\sigma) \mathrm{Ru}-\mathrm{CO}$

Fig. 4. Three d-orbital-shaped Ru lone pair NBOs 99, 101, 102 and $\sigma$ shaped $65 \mathrm{NBO}$ of $\mathrm{Ru}-\mathrm{C} 9 \mathrm{O}$ with isosurface values of 0.09 are recorded.

$\left.101 \mathrm{~d} x^{2}-y^{2}, 102 \mathrm{~d}^{y z}\right)$ appear on the $\mathrm{Ru}$ atom. Thus, the computed Lewis structure of $\mathrm{Ru}-\mathrm{L}$ indicates a d6-electron configuration for the $\mathrm{Ru}$ atom.

The plotted shapes of two $\mathrm{C}=\mathrm{O}$ ligands NBOs show that each $\mathrm{C}=\mathrm{O}$ ligand consists of one $\mathrm{BD}$ $\sigma$-bond orbital (NBOs 42 or 43), two perpendicular $\pi$ bonds (BD NBOs 86,90 or 87,89 ) and one LP orbital (NBOs 52 or 51) for oxygen. The BD NBOs 65 and 66 represent the axial and equatorial $\sigma$ bonds of $\mathrm{Ru}-\mathrm{C} 9 \mathrm{O}$ and $\mathrm{Ru}-\mathrm{C} 8 \mathrm{O}$, respectively. The axial NBO 65 of Ru-C9O has the energy of -0.579 a.u., the electron occupation number 1.99 and the Wiberg bond index (WI) 1.23, as reported in Table 1 and represented in Fig. 3. The energy of equatorial $66 \cdot \operatorname{BD}(\sigma)$ $\mathrm{Ru}-\mathrm{C} 8 \mathrm{O}$ NBO is -0.369 a.u., the electron occupation number is 1.91 and WI 1.11, suggesting that the axial $\mathrm{Ru}-\mathrm{C} 9 \mathrm{O}$ bond may be somewhat stronger than the equatorial bond. As shown in Fig. 4, both $\sigma$-bond $\mathrm{Ru}-\mathrm{CO} \mathrm{NBOs}$ are polarized towards carbon. The WIs values higher than 1 suggest very strong covalent $\mathrm{Ru}-\mathrm{CO}$ bonds.

An interesting bonding nature has been observed for the $\mathrm{Ru}$ and $\mathrm{N}$ interaction. This bonding is localized on the $\mathrm{N}$ atom, as can be seen from the NBO plot of the 0.17 isovalue in Fig. 5(a).

The shape of $\operatorname{LP}(\sigma) \mathrm{N}$ NBO 91 is associated with the lone pair out-of-phase electron donation from the $\sigma$-lone pair atomic orbital (AO) component of $\mathrm{N}$ to the $\mathrm{Ru}$ acceptor $\mathrm{AO}$ component associated with the lone pair $\mathrm{d} z^{2}$ orbital as obtained by drawing isosurface values of 0.03 (Fig. $5(\mathrm{~b})$ ). Actually, the $\operatorname{LP}(\sigma) \mathrm{NBO}$ of $\mathrm{N}$ represents a highly polarized 

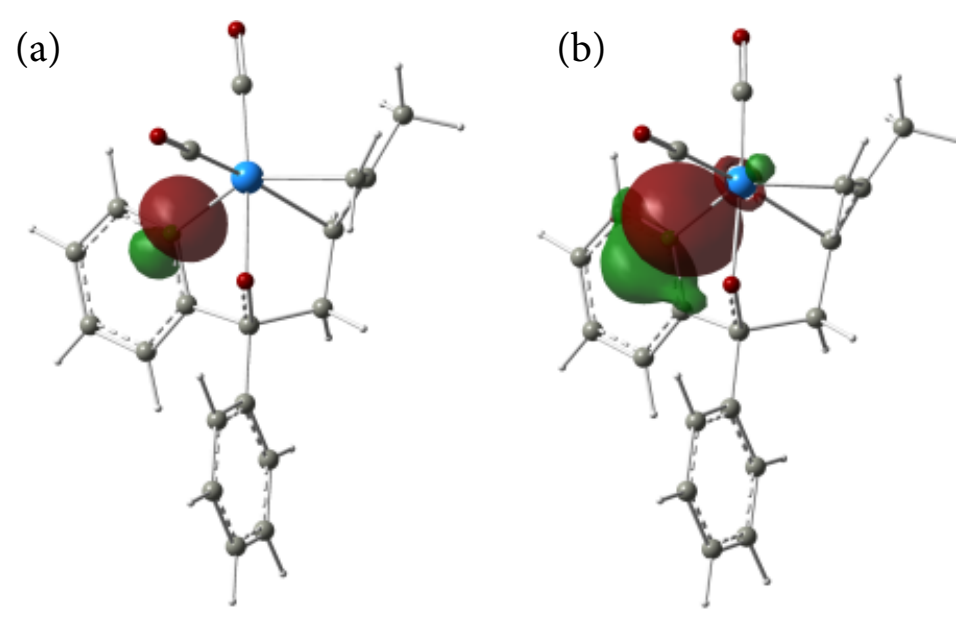

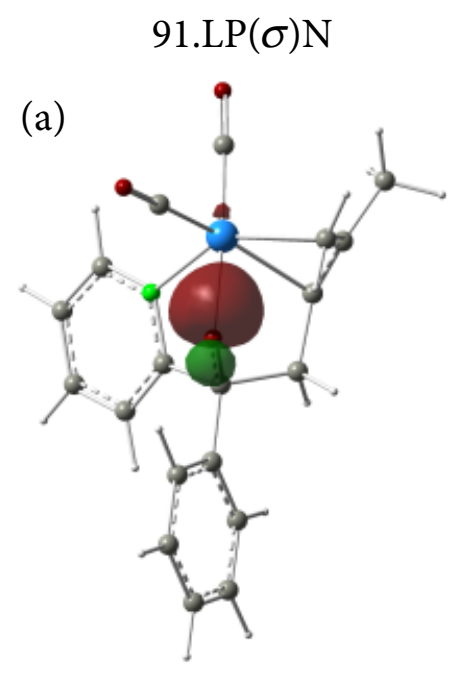

88. $\mathrm{BD}(\sigma) \mathrm{Ru}-05^{\prime}$

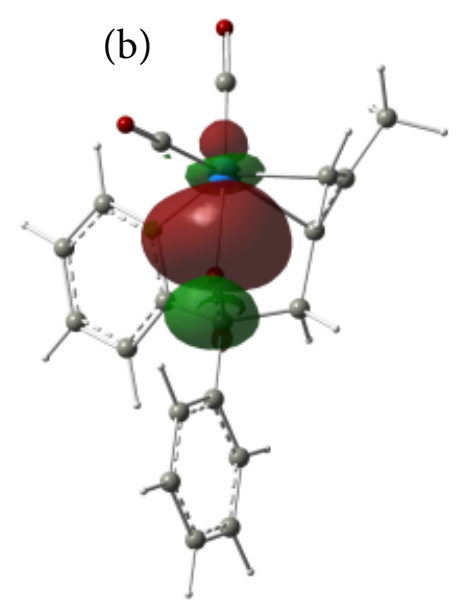

88.BD $(\sigma) \mathrm{Ru}-\mathrm{O} 5$

Fig. 5. The $\sigma$ shaped lone pair $91 \mathrm{NBO}$ of $\mathrm{N}$ atom and $\mathrm{Ru}-\mathrm{O} 5{ }^{\prime} \sigma$ type $88 \mathrm{NBO}$ are recorded with the isosurface values: 0.17 (a) and $0.03(b)$.

bond sharing a pair of electrons with the electron deficient $\mathrm{Ru} \mathrm{d} z^{2} \mathrm{AO}$. This suggests that the $\mathrm{N}$ atom is involved in the dative donor-acceptor ionic bond with the $\mathrm{Ru}$ atom.

In contrast to the $\mathrm{LP}(\sigma) \mathrm{NBO}$ of $\mathrm{N}$, the shape of $\mathrm{NBO} 88$ on $\mathrm{Ru}-\mathrm{O}^{5}$ is related to the $\mathrm{BD} \sigma$ orbital which consists of in-phase oriented lone pair AOs electrons of $\mathrm{Ru}$ and $\mathrm{O}^{\prime}$ atoms (Fig. 5(a)). It emerges through the in-phase electron donation from the $\mathrm{sp}^{5}$ hybridized $\sigma$-lone pair AO component of $\mathrm{O}^{\prime}$ to the $\mathrm{Ru}$ lone pair $\mathrm{d} z^{2}$ AO component (Fig. 5(b)). The electron occupation number is 1.90 and $\mathrm{WI}$ is 0.36 . The electron polarization towards O5' ranges up to $82.38 \%$ and the calculated bond ionicity is equal to 0.648 , which reveals the donor-acceptor ionic bond character of the axial $\mathrm{Ru}-\mathrm{O} 5$ ' bond.
The obtained results show that $\sigma$-ED is the first step in the DCD model (Fig. 1) covered by the computed Lewis structure of Ru-L (Figs. 2-5).

The qualitative estimation EBD of the DCD model (Fig. 1) is presented below. Weinhold et al. applied the second-order perturbation theory [21] to show the interactions between strongly occupied donor NBOs and weakly occupied antibonding acceptor NBOs of a molecule. Within this theory, the HF F-matrix is represented in the complete NBO basis set. Diagonal matrix elements, referred to as $\mathrm{BD}, \mathrm{LP}$ and CR NBOs, form the unperturbed system. The perturbation of the unperturbed system is represented by off-diagonal F-matrix elements. This F-matrix partitioning leads to the second-order energies $E^{(2)}$. Strong donor-acceptor NBO interactions are reflected 
by large $E^{(2)}$ values. The obtained largest $E^{(2)}$ values (higher than $33.0 \mathrm{~kJ} / \mathrm{mol}$ ) for donor-acceptor interactions are recorded in Table 2. Strongly occupied donor NBOs interacting with $\pi^{\star}$ NBOs are given in the second column ( $i$ ) of Table 2. The acceptor NBOs weakly occupied antibonding $\pi^{\star} \mathrm{LP}^{\star}$ and $\mathrm{BD}^{\star} \mathrm{NBO}$ are given in the third $(j)$ column, and the second-order interaction energies $E^{(2)}$ are given in the fourth column.

Entries 2-4 reveal EBD processes occurring from the BD NBOs of $\mathrm{Ru}-\mathrm{C} 1$ and $\mathrm{Ru}-\mathrm{C} 3$ to $\pi^{*}$ antibonding NBOs of the $\mathrm{LP}^{*} \mathrm{C} 2(\pi)$ and $\mathrm{BD}^{*}$ $\mathrm{O}^{\prime}(\mathrm{p})-\mathrm{Ru}$ bond regions. The $E^{(2)}$ values show that the bonds of $\mathrm{Ru}-\mathrm{C} 1$ and $\mathrm{Ru}-\mathrm{C} 3$ in the $\mathrm{Ru}-\mathrm{L}$ act as strong electron donors with $E^{(2)}$ values of 878.598 and $1371.139 \mathrm{~kJ} / \mathrm{mol}$, respectively. Thus, the donating ability operates in elongation and weakening of the $\mathrm{Ru}-\mathrm{C} 3$ bond with a greater extent of $492.541 \mathrm{~kJ} / \mathrm{mol}$ as compared to $\mathrm{Ru}-\mathrm{C} 1$. This result agrees with trends of the $\mathrm{Ru}-\mathrm{C} 1$ and $\mathrm{Ru}-\mathrm{C} 3$ bond strengths. The longer and weaker $\mathrm{Ru}-\mathrm{C} 3$ bond was obtained by calculation and experiment as compared to $\mathrm{Ru}-\mathrm{C} 1$. It is also important to stress that the highest accepting ability has been detected for $104 . \mathrm{LP}^{\star}(\pi) \mathrm{C} 2$ due to highly expressed EBD transfer mainly operating from $\mathrm{LP}(\mathrm{d}) \mathrm{Ru}$ NBOs, Ru-C3 and Ru-C1 NBOs to 104 . LPC2 (entries 2, 3, 5, 7, 12). Such high electron transfer (of $2486.175 \mathrm{~kJ} / \mathrm{mol}$ ) explains why formally vacant antibonding $\mathrm{NBO} 104 . \operatorname{LP}^{\star}(\pi) \mathrm{C} 2$ is characterized by the highest electron occupation number 0.881 and the lowest energy -0.141 a.u. The overall EBD contribution to $\rightarrow 104 . \mathrm{LP}^{\star}(\pi) \mathrm{C} 2$ NBO is equal to $E^{(2)}=2486.175 \mathrm{~kJ} / \mathrm{mol}$. This suggests that this NBO to the largest extent contributes to the stabilization of $\mathrm{Ru}-\mathrm{L}$.

The analysis of the interaction energies of $\mathrm{Ru}-\mathrm{C} 9=\mathrm{O}$ and $\mathrm{Ru}-\mathrm{C} 8=\mathrm{O}$ bondings agrees with the trends observed in the calculated bond distances and bond orders. The compiled $E^{(2)}$ values show that the $\mathrm{C} 9=\mathrm{O}$ and $\mathrm{C} 8=\mathrm{O}$ antibonding $\pi^{\star}$ NBOs most effectively interact with the Ru atom LP(d) NBOs. The highest electron transfer energies of EBD from $\mathrm{Ru} \mathrm{LP}(\mathrm{d}) \mathrm{NBO}$ to $\mathrm{BD}\left(\pi^{\star}\right)$ $\mathrm{C} 9=\mathrm{O}$ and $\mathrm{BD}\left(\pi^{\star}\right) \mathrm{C} 8=\mathrm{O}$ are equal to 505.469 and 195.225 kJ/mol, respectively. As shown in Fig. 1, the donating ability from the Ru LP(d) NBOs operates in weakening of the $\mathrm{C} 9=\mathrm{O}$ bond and strengthening of the $\mathrm{Ru}-\mathrm{C} 9$ bond. As seen from entries $8-13$, the $\pi$-back-donation from the $\mathrm{Ru}$ $\mathrm{LP}(\mathrm{d})$ orbitals to the formally vacant antibonding $\pi^{*}$ orbitals of $\mathrm{C}=\mathrm{O}$ operates in strengthening of the $\mathrm{Ru}-\mathrm{C} 9$ bond and weakening of $\mathrm{C} 9=\mathrm{O}$ with a greater extent of $310.244 \mathrm{~kJ} / \mathrm{mol}$ as compared to $\mathrm{Ru}-\mathrm{C} 8=\mathrm{O}$ bonding strengthening variations.

The calculation shows that the shorter axial $\mathrm{Ru}-\mathrm{C} 9 \mathrm{O}$ bond distance leads to an increase in the $\mathrm{C} 9=\mathrm{O}$ bond length and, conversely, the longer equatorial $\mathrm{Ru}-\mathrm{C} 8 \mathrm{O}$ bond distance leads to a decrease in the $\mathrm{O}=\mathrm{C} 8$ bond length.

Table 2. Second-order interaction energies $E^{(2)}$ characterizing the interactions between bond (BD) and lone pair (LP) donor NBOs and the electron accepting antibonding $\mathrm{p}^{*}-\mathrm{NBO}$ of carbonyl ligands are listed with a threshold higher than $33 \mathrm{~kJ} / \mathrm{mol}$.

\begin{tabular}{|c|c|c|c|}
\hline Entry & Donor NBO $(i)$ & Acceptor NBO (j) & $E^{(2)} \mathrm{kJ} / \mathrm{mol}$ \\
\hline 1 & 91.LP $(\sigma) \mathrm{N}$ & 118.LP ${ }^{*}(\mathrm{~d}) \mathrm{Ru}$ & 327.021 \\
\hline 2 & 103. $\mathrm{BD}(\sigma) \mathrm{C} 3-\mathrm{Ru}$ & 104.LP ${ }^{\star} \mathrm{C} 2(\pi)$ & 1371.139 \\
\hline 3 & 95. $\mathrm{BD}(\sigma) \mathrm{C} 1-\mathrm{Ru}$ & 104.LP ${ }^{\star} \mathrm{C} 2(\pi)$ & 878.598 \\
\hline 4 & 95. $\mathrm{BD}(\sigma) \mathrm{C} 1-\mathrm{Ru}$ & $118 . \mathrm{BD}^{\star}(\mathrm{p}) \mathrm{O}^{\prime}-\mathrm{Ru}$ & 45.606 \\
\hline 5 & 102.LP(d)Ru & 104.LP ${ }^{\star} \mathrm{C} 2(\pi)$ & 56.526 \\
\hline 6 & 102.LP(d)Ru & $108 . \mathrm{BD}^{*}(\pi) \mathrm{C} 9=\mathrm{O}$ & 131.587 \\
\hline 7 & 101.LP(d)Ru & 104.LP* $\mathrm{C} 2(\pi)$ & 144.725 \\
\hline 8 & 101.LP(d)Ru & 109. $\mathrm{BD}^{*}(\pi) \mathrm{C} 8=\mathrm{O}$ & 116.441 \\
\hline 9 & 99.LP(d)Ru & 113. $\mathrm{BD}^{*}(\pi) \mathrm{C} 8=\mathrm{O}$ & 78.785 \\
\hline 10 & 99.LP(d)Ru & $110 . \mathrm{BD}^{*}(\pi) \mathrm{C} 9=\mathrm{O}$ & 110.709 \\
\hline 11 & 102.LP(d)Ru & $108 . \mathrm{BD}^{*}(\pi) \mathrm{C} 9=\mathrm{O}$ & 131.587 \\
\hline 12 & 99.LP(d)Ru & 104.LP ${ }^{\star} \mathrm{C} 2(\pi)$ & 35.187 \\
\hline 13 & 4.CR Ru & $158 . \mathrm{BD}^{*}(\pi) \mathrm{C} 9=\mathrm{O}$ & 49.8314 \\
\hline
\end{tabular}


In addition, the outcome of $E^{(2)}$ computations points out to the main contributions $\operatorname{LP}(\sigma) \mathrm{N}$ $91 \rightarrow 118 . \mathrm{LP}^{\star}\left(\mathrm{d} z^{2}\right) \mathrm{Ru}$. The $\mathrm{LP}(\sigma) \mathrm{N}$ atom contributes as a strong electron donor with the $E^{(2)}$ value of $327.021 \mathrm{~kJ} / \mathrm{mol}$ as collected by entry 1 . This observation suggests the pronounced participation of the $\mathrm{LP}(\sigma) \mathrm{N} 91 \mathrm{NBO}$ in the $\sigma \mathrm{ED}$.

As expected, the donating or accepting nature of the ligand bonds to Ru expressed by the analysis of $E^{(2)}$ energies, characterizing the size of electron transfer between $\mathrm{Ru}$ and the ligand, is in agreement with the observed shortening of axial $\mathrm{Ru}-\mathrm{C} 9 \mathrm{O}$ and elongation of equatorial $\mathrm{Ru}-\mathrm{C} 8 \mathrm{O}$ bond distances, as well as explains the presence of a stronger and more covalent $\mathrm{Ru}-\mathrm{C} 1$ bond as compared to $\mathrm{Ru}-\mathrm{C} 3$.

In summary, the above results show that, first, the preferential $\sigma \mathrm{ED}$ operates from the occupied orbitals on $\mathrm{N}, \mathrm{C} 1, \mathrm{C} 3$ and $\mathrm{O}^{\prime}$ atoms into the vacant orbitals of the central $\mathrm{Ru}$ atom; secondly, the EBD transfer operates mostly effectively from the $\mathrm{LP}(\mathrm{d}) \mathrm{NBO}$ of the Ru atom and $\mathrm{BD}(\sigma) \mathrm{NBO}$ of $\mathrm{Ru}-\mathrm{C} 1$ and $\mathrm{Ru}-\mathrm{C} 3$ into the antibonding $\mathrm{BD}^{\star}(\pi)$ NBOs of both $\mathrm{CO}$ groups and the $\mathrm{C} 2$ atom of the allyl fragment. The $\mathrm{C} 9=\mathrm{O}$ and $\mathrm{C} 8=\mathrm{O}$ bonds dominate as electron acceptors. The $\mathrm{Ru}-\mathrm{C} 1$ and $\mathrm{Ru}-\mathrm{C} 3$ $\mathrm{BD}(\sigma) \mathrm{NBO}$ in the $\mathrm{Ru}$-complex act as strong electron donors.

Aiming to confirm the results obtained from electron transfer characterization of the $E^{(2)}$ analysis, the role of electron delocalization has also been quantitatively assessed by the CDA [23]. This method was developed for TM complexes with the aim to analyse chemical bonding within a framework of the DCD model.

\subsection{Charge decomposition analysis and idealized natural Lewis structure}

CDA is a quantitative expression of the metal to ligand bonding which considers the ligand $\rightarrow$ TM $\sigma$-ED and ligand $\leftarrow$ TM $\pi$-EBD as the dominant factors for the TM to ligand bond. In the CDA, the wave function of the L-TM-X complex is expressed as a linear combination of the molecular orbital of fragments in closed-shell configurations of the ligand (X) and the remaining TM and ligand fragment L-TM. Orbital contributions of the fragments to the wave function of the L-TM-X complex are divided into four parts: (i) mixing of the occupied MOs of $\mathrm{X}$ and the unoccupied MOs of L-TM (ED action X $\rightarrow$ TM-L); (ii) mixing of the unoccupied MOs of $\mathrm{X}$ and the occupied MOs of L-TM (back-donation $\mathrm{X} \leftarrow \mathrm{TM}-\mathrm{L}$ ); (iii) mixing of the occupied MOs of $\mathrm{X}$ and the occupied MOs of L-TM (repulsive polarization $\mathrm{X} \mathrm{T} \leftrightarrow \mathrm{TM}-\mathrm{L}$ ). Since the donation and the back-donation are calculated for each MO separately, it is possible to estimate the contributions of the ligand $\rightarrow$ TM $\sigma$-donation and ligand $\leftarrow$ TM $\pi$-back-donation to the total charge exchange. The CDA may be used in conjunction with HF MOs and with KohnSham orbitals as well as NBOs obtained by means of DFT calculations [23].

In this work, the charge donation $\left(q_{\mathrm{d}}\right)$, charge back-donation $\left(q_{\mathrm{b}}\right)$ and repulsive polarization $\left(q_{\mathrm{r}}\right)$ between the $\mathrm{Ru}-\mathrm{L}$ molecular orbital fragments have been calculated as implemented in the CDA method (Table 3). Within this method, the interaction between donor fragment $\mathrm{A}$ and acceptor fragment $\mathrm{B}$ is partitioned into three terms: the electron donation from $\mathrm{A}$ to $\mathrm{B}$, the electron donation from $\mathrm{B}$ to $\mathrm{A}$ and the reorganization due to the electron repulsion in the bonding region. Considering the outcomes of $\mathrm{NBO} E^{(2)}$ characterizing the donating and accepting abilities of the relevant $\mathrm{Ru}-\mathrm{L}$ bonds, the oxapyridine moiety was defined as an A donor fragment and the remaining $\mathrm{Ru}$ atom, two carbonyl groups and C2 within the $\pi$-allyl ligand were defined as a B electron acceptor. Table 2 summarizes the total amounts of donation $q_{\mathrm{d}}(\mathrm{A} \rightarrow \mathrm{B})$, back-donation $q_{\mathrm{b}}(\mathrm{A} \leftarrow \mathrm{B})$ and repulsion $q_{\mathrm{r}}(\mathrm{A} \leftrightarrow \mathrm{B})$ of $\mathrm{Ru}-\mathrm{L}$, which were assessed by computation at the DFT-B3LYP/ SVP and HF/SVP levels of theory.

The positive values of $q_{\mathrm{d}}(\mathrm{A} \rightarrow \mathrm{B}), q_{\mathrm{b}}(\mathrm{A} \leftarrow \mathrm{B})$ and the negative $q_{\mathrm{r}}(\mathrm{A} \leftrightarrow B)$ are found at the HF and DFT levels of theory indicating that the electronic structure of $\mathrm{Ru}-\mathrm{L}$ can be characterized by the DCD model as a typical donor-acceptor complex. The negative $q_{r}(\mathrm{~A} \leftrightarrow \mathrm{B})$ value indicates the electronic charge removal from the overlapping region between the occupied molecular orbitals. A meaningful quantity is the ratio of $q_{\mathrm{d}} / q_{\mathrm{b}}$. It shows what an amount of EBD operates in the $\mathrm{Ru}-\mathrm{L}$ with respect to ED. As shown in Table 3, the $q_{\mathrm{d}} / q_{\mathrm{b}}$ ratio demonstrates an increase in EBD as compared to ED when the method changes from restricted HF to DFT. This confirms the importance of electron correlation effects in EBD as implemented in DFT. 
Table 3. The total amounts of donation $q_{\mathrm{d}}(\mathrm{A} \rightarrow \mathrm{B})$, back-donation $q_{\mathrm{b}}(\mathrm{A} \leftarrow \mathrm{B})$ and repulsion $q_{\mathrm{r}}(\mathrm{A} \leftrightarrow \mathrm{B})$ of $\mathrm{Ru}-\mathrm{L}$ at the DFT-B3LYP/SVP and HF/SVP levels of theory between the Ru-L molecular orbital fragments. The charge donation $q_{\mathrm{d}}$, charge back donation $q_{\mathrm{b}}$ and repulsive polarization $q_{\mathrm{r}}$. The oxapyridine moiety is defined as an $\mathrm{A}$ donor fragment, and the remaining Ru atom, two carbonyl groups and C2 within the $\pi$-allyl ligand as a B electron acceptor.

\begin{tabular}{ccc}
\hline CDA terms & HF & DFT \\
\hline$q_{\mathrm{d}}(\mathrm{A} \rightarrow \mathrm{B})$ & 5.527 & 0.962 \\
\hline$q_{\mathrm{b}}(\mathrm{A} \leftarrow \mathrm{B})$ & 0.306 & 0.795 \\
\hline$q_{\mathrm{r}}(\mathrm{A} \leftrightarrow \mathrm{B})$ & -5.559 & -3.827 \\
\hline Ratio $q_{\mathrm{d}} / q_{\mathrm{b}}$ & 18.062 & 1.210 \\
\hline
\end{tabular}

Aiming to confirm the results obtained from electron transfer characterization of the $E^{(2)}$ analysis and CDA results, the role of electron delocalization has also been assessed by elimination of the non Lewis NBOs from the basis set. This procedure results in the idealized localized natural Lewis structure of $\mathrm{Ru}-\mathrm{L}(\mathrm{I}-\mathrm{Ru}-\mathrm{L})$ wave function possessing all Lewis-type NBOs doubly occupied by electrons. It gives a quantitative estimation on how the stabilizing effects of electron delocalization contribute to the total energy changes in the Lewis structure of $\mathrm{Ru}-\mathrm{L}$. Important energy quantities, resulting from the deletion procedure of the $\mathrm{Ru}-\mathrm{L}$ ground state optimized wave function by means of HF and DFT, are

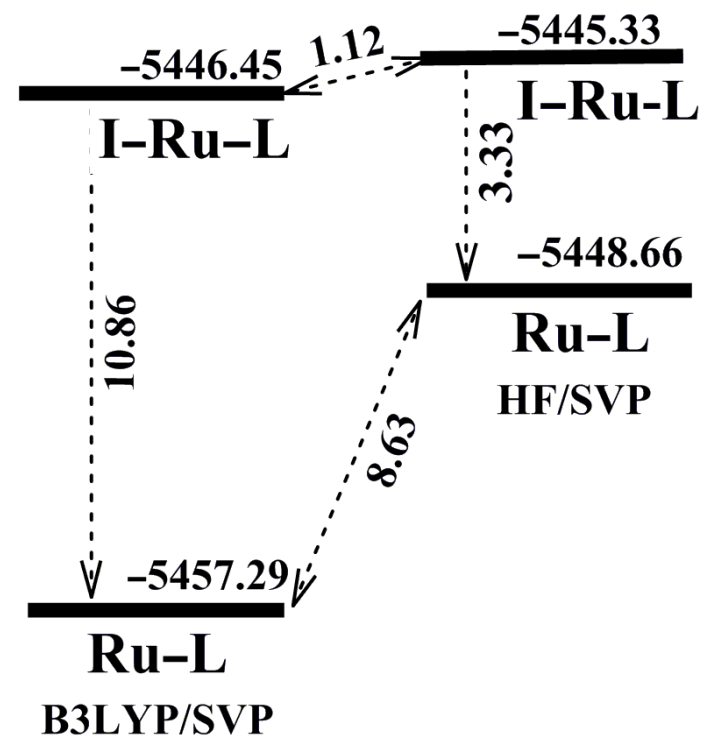

Fig. 6. The total energies (in a.u.) are presented for the computed Lewis structure of the $\mathrm{Ru}-\mathrm{L}$ complex $(\mathrm{Ru}-$ L) andfor the idealized Lewis structure (I-Ru-L), obtained by elimination of non-Lewis NBOs from the basis set. The calcutations were performed at the B3LYP/SVP and HF/SVP levels. compiled in Fig. 6. The electron correlation was defined as the difference between the DFT energy and the energy obtained from the solved HF equation.

The energy of the Lewis structure $\mathrm{Ru}-\mathrm{L}$ calculated at HF/SVP level is -5448.6617 a.u. The electron correlation turns out the total energy to DFT $=-5457.2921$ a.u. and leads to the energy lowering by 8.63 a.u. for the Lewis structure of $\mathrm{Ru}-\mathrm{L}$. The deletion procedure of all non-Lewis NBOs leads to the I- Ru-L wave function and increases the energy to DFT $=-5446.4469$ a.u. and $\mathrm{HF}=-5445.3279$ a.u. It means that the electron transfer action from the $\mathrm{I}-\mathrm{Ru}-\mathrm{L}$ to $\mathrm{BD}^{*}$ and $\mathrm{LP}^{\star} \mathrm{NBO}$ of the Lewis structure $\mathrm{Ru}-\mathrm{L}$ is important in stabilization of $\mathrm{Ru}-\mathrm{L}$. This electron transfer decreases the energy of the Lewis structure of $\mathrm{Ru}-\mathrm{L}$ by 10.85 and 3.34 a.u. for DFT and HF, respectively. This suggests that electron transfer in $\mathrm{Ru}-\mathrm{L}$ is influenced by electron correlation effects as implemented in the DFT method.

\section{Conclusions}

Aiming to provide detailed insights into the electronic structure and explain the transition metal to ligand bonding nature the DFT-B3LYP/SVP calculation has been applied for the $\pi$-allylruthenacycle complex $(\mathrm{Ru}-\mathrm{L})$. The computational natural bond orbital analysis (NBO) in conjunction with the charge decomposition analysis (CDA) reveals the Dewar-Chatt-Duncanson (DCD) model operation within the $\mathrm{Ru}-\mathrm{L}$.

The relevant calculated geometry parameters, vibration frequencies and electron density arrangement within the $\mathrm{Ru}-\mathrm{L}$ complex are determined to be in good agreement with the experiment and support the DCD model. 
The electron donation proceeds mainly from the $\mathrm{N}$ atom (of pyridine moiety), C1, C3 atoms (of $\pi$-allyl group) and $\mathrm{O} 5$ atom to the central $\mathrm{Ru}$ atom forming $\sigma$ NBOs.

The electron back-donation (EBD) transfer most effectively proceeds from three lone pair $\mathrm{LP}(\mathrm{d}) \mathrm{Ru}$ NBOs into two unoccupied bond $\mathrm{BD}^{*}(\pi)$ $\mathrm{CO}$ and $\mathrm{LP}^{\star}(\mathrm{p}) \mathrm{C} 2 \mathrm{NBOs}$.

The strengths and vibration frequencies of $\mathrm{Ru}-\mathrm{C}$ and $\mathrm{Ru}-\mathrm{C}=\mathrm{O}$ bonds coincide well with electron transfer energies proposed by the NBO Weinhold perturbation theory.

The lone pair of $\mathrm{N}$ atom $\mathrm{LP}(\sigma) \mathrm{N}$ contributes as a strong donor transferring electron density into the antibonding lone pair $\mathrm{LP}^{\star}\left(\mathrm{d} z^{2}\right) \mathrm{Ru}$ NBO.

The $\mathrm{C} 2$ atom exhibits extremely high electron accepting power (of $2486.175 \mathrm{~kJ} / \mathrm{mol}$ ) as compared to other bonds. The $\pi \mathrm{C} 9=\mathrm{O}$ and $\mathrm{C} 8=\mathrm{O}$ bonds clearly dominate as electron acceptors.

The energy of the Lewis Ru-complex as compared to that of the idealized Lewis structure gets lowered by the contribution of electron donation and electron back-donation processes. The highly prominent electron back-donation to the lone pair antibonding $\mathrm{LP}^{\star}(\mathrm{p}) \mathrm{C} 2 \mathrm{NBO}$ most efficiently stabilizes the $\mathrm{Ru}-\mathrm{L}$ complex. The electron transfer is influenced by electron correlation effects.

\section{Acknowledgements}

Computations were performed on resources at the High Performance Computing Center 'HPC Sauletekis' in the Vilnius University Faculty of Physics.

\section{References}

[1] J.F. Hartwig, Carbon-heteroatom bond formation catalysed by organometallic complexes, Nature 455, 314322 (2008), https://doi.org/10.1038/nature07369

[2] J. Twilton, C. Le, P. Zhang, M.H. Shaw, R.W. Evans, and D.W.C. MacMillan, The merger of transition metal and photocatalysis, Nat. Rev. Chem. 1, 118 (2017), https://doi.org/10.1038/s41570-017-0052

[3] M.S. Mehata, Y. Yang, Z.J. Qu, J.S. Chen, F.J. Zhao, and K.L. Han, Spin mixed charge transfer states of iridium complex $\operatorname{Ir}($ ppy)3: transient absorption and time-resolved photoluminescence, RSC
Adv. 5, 3409499 (2015), https://doi.org/10.1039 c5ra01404b

[4] K. Kalyanasundaram and M. Grätzel, Applications of functionalized transition metal complexes in photonic and optoelectronic devices, Coord. Chem. Rev. 177, 347414 (1998), https://doi. org/10.1016/S0010-8545(98)00189-1

[5] M. Gerloch and E.C. Constable, Transition Metal Chemistry (VCH, Weinheim, 1994), https://doi. org/10.1002/bbpc.19950990619

[6] E.C. Constable, Metals and Ligand Reactivity (VCH, Weinheim, 1996), https://doi.org/10.1002 ange.19961081541

[7] Ch. Elschenbroich and A. Salzer, Organometallics, 2nd ed. (VCH, Weinheim, 1992), https://trove. nla.gov.au/version/42575974

[8] T.A. Albright, J.K. Burdett, and M.H. Whangbo, Orbital Interactions in Chemistry (Wiley, New York, 1985), https://www.fzu.cz/ knizek/literatura/Albright2013.pdf

[9] M.J.S. Dewar, A review of the $\pi$-complex theory, Bull. Soc. Chim. Fr. 18, C71-C79 (1951).

[10]J. Chatt and L.A. Duncanson, Olefin co-ordination compounds. Part III. Infra-red spectra and structure: attempted preparation of acetylene complexes, J. Chem. Soc., 2939-2947 (1953), https://doi.org/10.1039/JR9530002939

[11]F.A. Cotton and G. Wilkinson, Advanced Inorganic Chemistry (Wiley \& Sons, New York, 1980).

[12]R.K. Hocking and T.W. Hambley, Database analysis of transition metal carbonyl bond lengths: Insight into the periodicity of $\pi$ backbonding, $\sigma$ donation, and the factors affecting the electronic structure of the TM-C:O moiety, Organometallics 26, 2815-2823 (2007), https:// doi.org/10.1021/om061072n

[13]S.A. Decker and M. Klobukowski, The first carbonyl bond dissociation energies of $\mathrm{M}(\mathrm{CO})_{5}$ and $\mathrm{M}(\mathrm{CO})_{4}\left(\mathrm{C}_{2} \mathrm{H}_{2}\right)(\mathrm{M}=\mathrm{Fe}, \mathrm{Ru}$, and Os): The role of the acetylene ligand from a density functional perspective, J. Am. Chem. Soc. 120, 9342-9355 (1998), https://doi.org/10.1021/ja981197m

[14]G.N. Lewis, The atom and the molecule, J. Am. Chem. Soc. 38, 762-785 (1916), https://doi. org/10.1021/ja02261a002 
[15]J.M. Foster and S.F. Boys, Canonical configurational interaction procedure, Rev. Mod. Phys. 32, 300-302 (1960), https://doi.org/10.1103 RevModPhys.32.300

[16]C. Edmiston and K. Ruedenberg, Localized atomic and molecular orbitals, Rev. Mod. Phys. 35, 457-65 (1963), https://doi.org/10.1103 RevModPhys.35.457

[17]C.C.J. Roothaan, New developments in molecular orbital theory, Rev. Mod. Phys. 23(2), 69-88 (1951) https://doi.org/10.1103/RevModPhys.23.69

[18]C.Edmiston and K. Ruedenberg, Localized atomic and molecular orbitals. II, J. Chem. Phys. 43, S97S116 (1965), https://doi.org/10.1063/1.1701520

[19]W. England, L.S. Salmon, and K. Ruedenberg, Localized molecular orbitals: A bridge between chemical intuition and molecular quantum mechanics, Top. Curr. Chem. 23, 31-123 (1971), https://doi.org/10.1007/Bfb0051440

[20]F. Weinhold and C.R. Landis, Valency and Bonding: A Natural Bond Orbital Donor-Acceptor Perspective (Cambridge University Press, Cambridge, 2005).

[21]F. Weinhold, Natural Bond Orbital Methods, in: Encyclopedia of Computational Chemistry (Wiley, Chichester, 1998), https://doi. org/10.1002/0470845015.cna009

[22]C.R. Landis, A.E. Reed, L.A. Curtiss, and F. Weinhold, Intermolecular interactions from a natural bond orbital, donor-acceptor viewpoint, Chem. Rev. 88, 899-926 (1988), https://doi. org/10.1021/cr00088a005

[23]S. Dapprich and G. Frenking, Investigation of donor-acceptor interactions: a charge decomposition analysis using fragment molecular orbitals, J. Phys. Chem. 99, 9352-9362 (1995), https://doi. org/10.1021/j100023a009

[24]M.J. Frisch, G.W. Trucks, H.B. Schlegel, G.E. Scuseria, M.A. Robb, J.R. Cheeseman, G. Scalmani, V. Barone, B. Mennucci, G.A. Petersson, et al., Gaussian 09 (Gaussian Inc., Wallingford, CT, USA, 2009).

[25]A. Becke, Density-functional exchange-energy approximation with correct asymptotic behavior, Phys. Rev. A 38, 3098-3100 (1988), https://doi. org/10.1103/PhysRevA.38.3098
[26]Ch. Lee, W. Yang, and R.G. Parr, Development of the Colle-Salvetti correlation-energy formula into a functional of the electron density, Phys. Rev. B 37, 785-789 (1988), https://doi.org/10.1103/ PhysRevB.37.785

[27]F.-Q. Shi, X. Li, Y. Xia, L. Zhang, and Z.-X. Yu, DFT study of the mechanisms of in water $\mathrm{Au}(\mathrm{I})$ catalyzed tandem [3,3]-rearrangement/Nazarov reaction/[1,2]-hydrogen shift of enynyl acetates: a proton-transport catalysis strategy in the water-catalyzed [1,2]-hydrogen shift, J. Am. Chem. Soc. 129, 15503-15512 (2007), https://doi. org/10.1021/ja071070

[28]A. Becke, Density functional thermochemistry. III. The role of exact exchange, J. Chem. Phys. 98, 5648-5652 (1993), https://doi. org/10.1063/1.464913

[29]G. Kovacs, G. Ujaque, and A. Lledos, The reaction mechanism of the hydroamination of alkenes catalyzed by gold(i)-phosphine: the role of the counterion and the $\mathrm{N}$-nucleophile substituents in the proton-transfer step, J. Am. Chem. Soc. 130, 853-864 (2008), https://doi.org/10.1021 ja073578i

[30]A. Vektariene, G. Vektaris, and D.W.H. Rankin, DFT study of the regioselectivity of addition of sulfenylchloride to ethenes, Heteroatom Chem. 18(7), 695-703 (2007), https://doi.org/10.1002/ hc.20378

[31]R. Janciene, Z. Stumbreviciute, A. Vektariene, L. Kosychova, A. Klimavicius, A. Palaima, and B. Puodziunaite, Synthesis of novel annelated systems based on the interaction and reactivity estimation of amino-1,5-benzodiazepin-2-ones with dimethyl-2-oxoglutaconate, J. Heterocyclic Chem. 461, 339-1345 (2009), https://doi. org/10.1002/jhet.226

[32]R. Janciene, A. Vektariene, Z. Stumbreviciute, and B. Puodziunaite, Experimental and theoretical investigation of substituent effects in a twopathway reaction of tetrahydro-1,5-benzodiazepine-2-thiones, Monatsh. Chem. 142(6), 609-618 (2011), https://doi.org/10.1007/s00706011-0496-4

[33]A. Vektariene, Insights into the mechanism of the benzoannelated thieno[3,2-b]furan halogena- 
tion. Importance of HOMO-HOMO interaction, J. Phys. Chem. A 117, 8449-8458 (2013), https:// doi.org/10.1021/jp402257u

[34]G. Mazzone, N. Russo, and E. Sicilia, Homogeneous gold catalysis: hydration of 1,2-diphenylacetylene with methanol in aqueous media. A theoretical viewpoint, Organometallics 31, 3074-3080 (2012); J. Org. Chem. 79, 1954-1970 (2014), https://doi.org/10.1021/om2012369

[35]A.E. Ledesma, C. Contreras, J. Svoboda, A. Vektariene, and S.A. Brandan, Theoretical structures and experimental vibrational spectra of isomeric benzofused thieno[3,2-b] furan compounds, J. Mol. Struct. 1063, 356 (2014); J. Mol. Struct. 967, 159-165 (2010), https://doi. org/10.1016/j.molstruc.2014.01.087

[36]G. Mazzone, N. Russo, and E. Sicilia, Catalytic role of dinuclear $\sigma, \pi$-acetylide gold(i) complexes in the hydroamination of terminal alkynes: theoretical insights, J. Chem. Theory Comput. 11, 581-590 (2015), https://doi.org/10.1021 ct500849m

[37]A. Vektariene, Theoretical study on the mechanism of thieno[3,2-b]benzofuran bromination: the importance of Lewis and non-Lewis type NBOs interactions along the reaction path, J. Phys. Org. Chem. 29, 21-28 (2016), https://doi. org/10.1002/poc.3483

[38]A. Schaefer, C. Huber, and R. Ahlrichs, Fully optimized contracted Gaussian-basis sets of triple zeta valence quality for atoms $\mathrm{Li}$ to $\mathrm{Kr}$, J. Chem. Phys. 100, 5829-5835 (1994), https:// doi.org/10.1063/1.467146

[39]A. Schaefer, H. Horn, and R. Ahlrichs, Fully optimized contracted Gaussian basis sets for atoms Li to Kr, J. Chem. Phys. 97, 2571-2577 (1992), https://doi.org/10.1063/1.463096

[40]B.Y. Park, T.P. Montgomery, V.J. Garza, and J.M. Krische, Ruthenium catalyzed hydrohydroxyalkylation of isoprene with heteroaromatic secondary alcohols: isolation and reversible formation of the putative metallacycle intermediate, J. Am. Chem. Soc. 135, 16320-16323 (2013), https://doi.org/10.1021/ol401184k

[41]V. Jonas, G. Frenking, and M.T. Reetz, Comparative theoretical study of Lewis acid-base complexes of $\mathrm{BH}_{3}, \mathrm{BF}_{3}, \mathrm{BCl}_{3}, \mathrm{AlCl}_{3}$, and $\mathrm{SO}_{2}, \mathrm{~J}$. Am. Chem. Soc. 116, 8741-8753 (1994), https://doi. org/10.1021/ja00098a037

[42]P. Jerabek, H.W. Roesky, G. Bertrand, and G. Frenking, Coinage metals binding as main group elements: structure and bonding of the carbene complexes [TM(cAAC)2] and $[\mathrm{TM}(\mathrm{cAAC}) 2]+(\mathrm{TM}=\mathrm{Cu}, \mathrm{Ag}, \mathrm{Au}), \mathrm{J} . \mathrm{Am}$. Chem. Soc. 136, 17123-17135 (2014), https:// dx.doi.org/10.1021/ja508887s

[43] R. Dennington, T. Keith, and J. Millam, GaussView, Version 5.0.9 (Semichem, Inc., Shawnee Mission, KS, USA, 2009).

\title{
PEREINAMOJO METALO IR LIGANDO SAVEIKOS POBŪDIS: RUTENIO KOMPLEKSO ANALIZĖ, PAREMTA KVANTINĖS CHEMIJOS SKAIČIAVIMAIS
}

\author{
A. Vektarienè \\ Vilniaus universiteto Teorines fizikos ir astronomijos institutas, Vilnius, Lietuva
}

\section{Santrauka}

Žurnale Nature 2017 m. publikuoti darbai parodè, kad ryšių tarp pereinamojo metalo ir ligando pobūdis gali keisti fotokatalizès vyksmų eigą, daryti ịtaką elektro-liuminescenciniams procesams organiniuose ir šviesą skleidžiančiuose prietaisuose.

Darbe teoriškai nagrinèjama pereinamojo metalo ir ligando ryšių kilmè. Vienas iš metodų, aškinantis ligando ir pereinamojo metalo ryšio pobūdị, yra DewarChatt-Duncanson (DCD) modelis. Tačiau, aiškinant eksperimentą, DCD modelio galiojimas dažniausiai yra postuluojamas. Šiame darbe DCD modelio ga- liojimas rutenio cikliniame komplekse yra pagrịstas kvantinès chemijos skaičiavimais. Pasiūlyta skaičiavimo metodika remiasi tankio funkcionalo teorijos, natūralių ryšio orbitalių (angl. natural bond orbital), krūvio suskaidymo (angl. charge decomposition) analizès metodais. Skaičiavimo rezultatai, gauti remiantis straipsnyje aprašyta metodika, atskleide DCD modelio galiojimo ypatumus $\mathrm{Ru}$ komplekse. Apskaičiuoti $\mathrm{Ru}$ komplekso geometrijos parametrai ir svyravimų dažniai koreliuoja su eksperimentu ir yra suderinami su DCD modeliu. 